\title{
Influence of Corporate Culture on Performance of Commercial Banks in Kenya
}

\author{
Mr. Evans Silver Kwendo ${ }^{*}$, Dr. Ondoro Charles Omondi and Dr. Mise Jairo Kirwa^ \\ "PhD scholar, School of Business \& Economics, Maseno University, Kenya, \\ 'PhD Lecturers, School of Business \& Economics, Maseno University, Kenya
}

Received 12 July 2018, Accepted 15 Sept 2018, Available online 20 Sept 2018, Vol.6 (Sept/Oct 2018 issue)

\begin{abstract}
This study sought to investigate the influence of corporate culture on performance of commercial banks in Kenya. It adopted a quasi-experimental post test only research design. Primary data was collected from a sample of 136 senior managers at the 38 commercial banks' head-offices in Nairobi. Hypothesized relationships were tested using regression analysis. The results indicate that corporate culture positively and significantly influence banks performance. Therefore it is recommended that commercial banks have to build and nurture strong clan culture, adhocracy culture, market culture and hierarchy culture as key result areas.
\end{abstract}

Keywords: Corporate culture, clan culture, adhocracy culture, market culture and hierarchy culture, bank performance

\section{Introduction}

Hodgetts and Luthans (2003) define organizational culture as different features that are associated with how a firm undertakes it's day to day operations. Further, they content that norms as part of corporate culture can be measured by; the amount of work done, level of cooperation between management and employees, clearly defined rules to be followed, intergroup cooperation, customer relationships, common language used, formal procedures used and intergration between organizational units. However, Robbins and Sanghi (2007) describe organizational culture as common values exhibited by different employees with different backgrounds within an organization. Therefore, this implies that culture is an arrangement of different attributes that qualifies an organization and tries to distinguish it from how others behave when executing their daily activities. A strong corporate culture must be learned and shared amongst subordinates and managers in an organization. As such, it is a major responsibility of the management to ensure that employees understand the norms, values and objectives of the organization which contributes to culture of the company. This is important because when employees have full knowledge and are aware of organizational culture, they perform better in their work (Brooks, 2006).

Carneta, Farina and Schwizer (2006) concur that corporate culture is a set values and behavior in which an

*Corresponding author's ORCID ID: 0000-0002-0475-3910 DOI: https://doi.org/10.14741/ijmcr/v.6.5.7 organization undertakes its daily activities. They further agree that corporate culture is likely to enhance efficiency and effectiveness in the allocation of firm resources, by addressing the varied customers taste and preferences and offering quality products and services to satisfy them. An organization with good values is likely to group customers into segments and design different products to satisfy them. Cameron and Quinn (1999) identifies four types of organizational culture as; clan culture, adhocracy culture, market culture and hierarchy culture. The clan culture in an organization is experienced where exists: shared values, common goals, an atmosphere of collectivity and mutual help, staff empowerement and involvement, teamwork, stability loyalty and cohesiveness whereas adhocracy culture is a temporary behavior which is dismissed whenever work is over and reloaded when new work emerges. It gives staff a chance to be creative and therefore driven by innovations and new ideas from external environment.

The market culture focus on the activities outside the firm with a goal of profit maximization despite stiff competition while hierarchy culture is where there exists clear structure, standardised rules and procedures, strict control and well defined responsibilities which can be identified through; systems and procedures, stability within the firm and success is gauged on work performance. Wallach (1983) talks of three types of culture as: bureaucratic culture, supportive culture and innovative culture. Bureaucratic culture is one where rules and procedures are strictly followed and is good for repetitive work while supportive culture is one where employees and management work as a family. However, 
innovative culture focuses on the value of innovations to create a dynamic organization.

Carneta, Farina \& Schwizer (2006) assert that corporate culture refers to the set of values and behavior in which an organization undertakes its day-to-day activities. They further argue that corporate culture can be considered to be informal, control tool, based on social mechanisms and also formal control, which requires behavioral rules, codified procedures and organizational routines. They also agree that corporate culture is likely to enhance effectiveness in the allocation of firm resources, owing to a few key elements that succeed in addressing individual efforts towards common goals. Janicijevic (2012) defines corporate culture as shared beliefs, norms and values within an organization that sets the foundation for strategy formulation and implementation. He urgues that for a strategy to develop and be fully implemented, it must be aligned with corporate culture. Several studies conducted on the influence of corporate culture on firm performance, have revealed that corporate culture has strong and positive correlation on firm performance (Nyamongo \& Temesgen, 2013; Cook, 2008;Ugboro \& Obeng, 2000; Shahzad,et.al 2012;Steward, 2010; Oduol, 2015), while other studies showed that corporate culture could be a silent killer, if not aligned to firm strategy, mission and vision. These studies also revealed that corporate culture had a negative effect on performance among productivity dimensions in the market culture.

Studies on how corporate culture influences firm performance, have revealed conflicting results. The results of these studies were concluded on a single or few elements of corporate culture. Also, the studies failed to appreciate that individual chief executive officer's values differ and therefore their influence on firm performance is likely to differ, particularly among commercial banks in Kenya.

\subsection{Statement of the research problem}

Globally and locally, financial institutions enhance economic growth through financial assistance to business fraternity, which in turn facilitates to improvement in the standard of living of people. Despite this contribution, liberalization of the banking industry in Kenya in 1995 has made commercial banks to experience reduced profit margins and loss of customers. This is attributed to increased competition, raising financial costs and increased customer expectations. Consequently, studies have shown that the financial sector both globally and locally has experienced serious challenges such as; high customer expectations, increased competition, raising costs, advancement in technology, reduced profit margins, consistent fragmentation of customers' requirements and increased demand for non- traditional banking services. These challenges are likely to make commercial banks loose customers and profit margins. This can be attributed to weak corporate culture.
Therefore, commercial banks need to instill good corporate culture that would enhance their performance. Most studies carried out on how corporate culture influence firm performance have given conflicting results. Also, these studies failed to appreciate that individual CEO'S values differ and therefore their influence on performance is likely to differ, particulary among commercial banks in Kenya. Studies on how corporate culture influences firm performance have revealed mixed results. Therefore, there is insufficient information on the influence of corporate culture on performance of commercial banks in Kenya.

\subsection{Research objective and hypothesis}

To determine the influence of corporate culture on performance of commercial banks in Kenya

. $\mathbf{H}_{0}$ 2: Corporate culture does not influence commercial banks' performance.

\subsection{Corporate Culture and Performance of Banks}

A survey by Nyamongo and Temesgen (2013) on the effect of corporate governance on the performance of 37 commercial banks in Kenya over the period 2005 - 2009 indicated that large board of directors' size tends to impact negatively on performance while existence of small and independent board of directors had positive effect on banks' performance. They further found out that there is no evidence that chief executive officer's quality or otherwise had impact on performance of commercial banks in Kenya. Therefore, since people on Management resign or leave the organization, then there is need for continuous study on how individual behavior as part of corporate culture's influence on firm performance.

Cool (2008) in a study on customer service excellence, found out that service excellence will only be considered a critical success factor in business's long-term survival, if senior management demonstrate their involvement in terms of time, money effort, commitment, persistence and visibility. Therefore, if top management embrace good customer service in their corporate culture, then survival of their firms will be assured. Firms that put more effort into building customer - driven initiatives, are those whose service improvement efforts are driven, directed and guided by top management.

Another study by; Ugboro and Obeng (2000), revealed a positive correlation between top management leadership, employee empowerment, job satisfaction and customer satisfaction. Further, it discovered that top management practices are paramount towards ensuring better customer service. Other studies carried out on how individual management style influences performance indicate positive relationships between; management style, customer service and corporate performance (Emercy, College, Barker \& Fredonia, 2007, Verhoef, 2003, 
Dunford, Boss, Allan \& Wayne, 2009, Miah \& Bird, 2007, Alexandrov, Babakus \& Yavas, 2007). Research by; Rogg, Schmidt, Shull and Neal (2001), on human resource practices, organizational climate and customer satisfaction, revealed that indirect effects of human resource practices on customer satisfaction were significant, whereas, the direct effect was not significant. Shahzad, Luqman, Khan and Shabir (2012) in a survey on the impact of organizational culture on organizational performance at institute of interdisciplinary business research, found out that organizational culture had deep impact on the variety of company's process, employees and it's performance. This study also showed that if employees are committed and share the same norms and values of the company, overall performance of the firm will improve. Therefore, managers have to cultivate a strong culture among themselves and employees in order to improve organizational performance. As per Stewart (2010) company norms and values have a strong effect on the employees, management and firm performance, while Farashahi and Molz (2005) observed that culture is a strength and can also be a weakness to firm performance. This shows mixed results. Oduol (2015) investigated the effect of organizational culture among commercial banks in Kenya. The research findings revealed that the provision of rules that provided clear instructions, procedures and processes for employees was the most prevalent culture that make staff do their work efficiently and improve bank performance. This study also found out dominant cultures in the banks to be; clear instructions \& procedures, employees involvement in decision making, clear staff obligations and adherence to regulations. Haakonsan et.al (2008) investigated how misalignments between organizational climate and leadership style would affect firm performance. The results of this study revealed that misalignments may lead to negative firm performance. Also Wilderom et.al (2000) conducted a study on organizational culture as a predictor of organizational performance and found out that organizational culture is a significant factor of firm performance, but can also be a silent killer if it does not concor with the firm's mission and vision. Aktas et.al (2011) \& Lee and Tseng (2005) in their study on the effect of organizational culture on organizational efficiency, found out that self-direction character of managers was influential in the clan culture on establishing planning and goals setting, whereas the stimulation character had the same effect in market cultures while negative relations were experienced among productivity described as efficiency dimensions in market culture and stability as well as information management that described as efficiency elements in hierachy culture.

Studies on how corporate culture influences firm performance, have revealed conflicting results. These studies on how corporate culture affects firm performance, were concluded on a single or few elements of corporate culture. Also, the studies failed to appreciate that individual chief executive officer's values differ and therefore their influence on firm performance is likely to differ, particularly among commercial banks. Consequently, corporate culture is very dynamic because individuals join and leave firms and therefore corporate culture is likely to change, thus calling for further studies on how it influences firm performance.

\subsection{Methodology}

The study adopted a quasi-experimental post-test only research design. Choice of this design was informed by the fact that the proposed study was explanatory in nature and sought to establish whether variations in performance of commercial banks in Kenya could be influenced by manipulations in customer segmentation and corporate culture. In line with observations by White and Sabarwal (2014), quasi experimental research designs test causal hypotheses using interventions on predetermined subjects. In essence therefore, the present study used commercial banks that already exist, with interventions being the independent variables. Further, Aussens, Boomsma and Snijders (2011); Shadish and Campbell (2002) observe that quasi-experimental posttest research design is an empirical intervention study that seeks to establish a causal effect relationship between two or more variables. It is also called causal comparative study that involves collecting data to make inferences about a population of interest at one point in time.

The target population for the present study included all senior managers drawn from the entire set of 42 registered commercial banks in Kenya. The target population was narrowed to a study population that comprised of Business Development Manager, Customer Relations Manager, Marketing Manager, and Operations Manager drawn from each of 38 commercial banks, leaving four banks for piloting. Choice of these categories of senior managers was based on the premise that they would have relevant information that would be used to establish the causal- link between corporate culture and bank performance. The study population therefore comprised a total of 152 senior managers stratified by position held.

The study adopted a census survey of all senior managers identified in the study population. Consequently, all the 152 senior managers were included in the sample. A census study was adopted since, as noted by Saunders et al., (2003), the units of study were not many. Besides, it is argued that a census provides a true measure of the population with no sampling error, and enhances validity of the study (Kothari, 2004).

The present study relied solely on primary data sources. Kothari (2011) asserts that primary data are those which are collected on the spot from the respondents by the researcher for the first time. Primary data is original and more suitable for the study at hand, because it captures the respondents' perceptions and 
experiences that are critical in achieving the research objectives.

The principle instrument for data collection in the present study was the senior managers' questionnaire. The reliability of the questionnaires was verified through examination of internal consistency of the measures. This was achieved by computing Cronbach's alpha reliability coefficients using the Statistical Package for Social Sciences (SPSS) version 22.To ascertain internal consistency of the developed questionnaire, a pilot study was conducted. A pilot study focuses on establishing the integrity of the tools or protocols designed specifically for the study. It is interested in finding out whether or not the tools works as expected and how they should be revised in the event that they fail to work (Eldridge et al., 2016). Piloting of the questionnaire was conducted on 16 senior managers drawn from the 4 commercial banks that were omitted from the final study population. Choice of banks omitted from the main study for the pilot study was to ensure that respondents do not mature with the tools and become a threat to internal validity of the Study.

Two forms of validity were used to validate the quantitative instrument (senior officers' questionnaire). The first form of validity was face validity which according to Bolarinwa (2015) is the judgment made based on scientific approach on whether the indicator used measures the required construct. Consequently, the researcher sought the opinion and assistance of the assigned supervisors on whether as per face value the questionnaire appeared suitable both in design and structure and whether it measured the required constructs. An evaluation of each item was made to find out whether it matched the given conceptual domain of customer segmentation, corporate culture and bank performance. This was confirmed albeit with suggestions for some changes which were implemented.

Content validity was the second validation form conducted. Content validity is viewed as the degree with which the instrument measures the required construct (Sangoseni, Hellman \& Hill, 2013). Sangoseni et al (2013) contend that an instrument can only achieve content validity if it undergoes a rational analysis by raters (experts) who have familiarity with the academic scope of study. The researcher therefore asked the supervisors and banking experts to critically examine the items measuring specific constructs with a view of ascertaining whether the full content pertaining to any given construct was represented in the items and whether such content was justified with evidence from literature. On close scrutiny, various suggestions for correction were made and the final questionnaire was then produced.

\subsection{Results of the Study}

The multiple regressions weights (see Table 1 ) shows that the leadership dimension of corporate culture $(\beta=0.652$, $P<0.05)$, and structure $(\beta=0.167, P<0.05)$ were significant predictors of bank performance. Team work ( $\beta$
$=0.137, P>0.05)$ and innovativeness $(\beta=0.171, P>0.05)$ were not statistically significant. An increase of 1 standard deviation in corporate structure would therefore result in a 0.167 standard deviations increase in bank performance holding the others constant; and, an increase of 1 standard deviation in leadership would lead to an increase of 0.652 standard deviations in bank performance holding the others constant.

Table 1 Coefficients: Bank Performance on Corporate Culture

\begin{tabular}{|c|c|c|c|c|c|c|}
\hline & \multirow[t]{2}{*}{ Model } & \multicolumn{2}{|c|}{$\begin{array}{l}\text { Unstandardized } \\
\text { Coefficients }\end{array}$} & \multirow{2}{*}{$\begin{array}{c}\text { Standardized } \\
\text { Coefficients } \\
\text { Beta }\end{array}$} & \multirow[t]{2}{*}{$\mathbf{T}$} & \multirow[t]{2}{*}{ Sig. } \\
\hline & & B & Std. Error & & & \\
\hline \multirow{5}{*}{1} & (Constant) & 1.486 & .250 & & 5.943 & .000 \\
\hline & Structure & .143 & .069 & .167 & 2.082 & .039 \\
\hline & Teamwork & .119 & .065 & .137 & 1.841 & .068 \\
\hline & Leadership & .489 & .106 & .652 & 4.625 & .000 \\
\hline & Innovativeness & .110 & .081 & .171 & 1.357 & .177 \\
\hline
\end{tabular}

a. Dependent Variable: Performance

Source: Research Data (2018)

The relationship between corporate culture and performance of commercial banks was modeled as:

$B P=0.167 S+1.137 T+0.652 L+0.171 I+0.363$

The model summary presented in Table 2 indicates $R^{2}$ of 0.637 which is significant. Likewise, the adjusted $R^{2}$ of 0.626 is also significant. The change is (0.637-0.626), which equals to 0.011 . This is below the level of 0.5 , suggested by Field (2005). Therefore, it implies that the model is valid and stable for prediction. Thus, it predicts variance in performance at $63.7 \%$. This indicated that corporate culture dimensions accounted for up to $63.7 \%$ of the variance in bank performance.

Table 2 Model Summary: Bank Performance on Corporate Culture

\begin{tabular}{cccccc}
\hline \hline Model & $\mathbf{R}$ & $\begin{array}{c}\mathbf{R} \\
\text { Square }\end{array}$ & $\begin{array}{c}\text { Adjusted R } \\
\text { Square }\end{array}$ & $\begin{array}{c}\text { Std. Error of the } \\
\text { Estimate }\end{array}$ & $\begin{array}{c}\text { Durbin- } \\
\text { Watson }\end{array}$ \\
1 & $.798^{\mathrm{a}}$ & .637 & .626 & .38178 & 1.212 \\
\hline \hline & \multicolumn{4}{c}{ a. Predictors: (Constant), Innovativeness, Teamwork, Structure, } \\
& Leadership \\
b. Dependent Variable: Performance \\
Source: Research Data (2018)
\end{tabular}

Moreover, the ANOVA results (Table 3 ) confirmed that a model relating corporate culture to bank performance would be statistically suitable $\left(F_{4,131}=57.567, p<0.05\right)$.

Table 3 ANOVA: Bank Performance on Corporate Culture

\begin{tabular}{ccccccc}
\hline \hline & Model & Sum of Squares & Df & Mean Square & $\mathbf{F}$ & Sig. \\
& Regression & 33.563 & 4 & 8.391 & 57.567 & $.000^{\text {b }}$ \\
1 & Residual & 19.094 & 131 & .146 & & \\
& Total & 52.657 & 135 & & & \\
\hline
\end{tabular}

a. Dependent Variable: Performance

b. Predictors: (Constant), Innovativeness, Teamwork, Structure and Leadership

Source: Research Data (2018) 


\subsection{Discussions of Findings}

The study sought to determine the influence of corporate culture on the performance of commercial banks in Kenya. Data exploration confirmed that commercial banks in Kenya highly take cognizance of corporate culture dimensions such as teamwork, structure, leadership and innovativeness. Multiple regressions further confirmed that together, the corporate culture dimensions account for up to $63.7 \%$ of the variations experienced in bank performance. Besides, leadership, structure and teamwork were found to be contributing positively and significantly to performance of the banks.

These findings are consistent with others that posited positive correlations between corporate culture and firm performance (Ugboro \& Obeng, 2000; Shahzad et.al 2012; Wilderom et.al 2000). Further, the findings of this study concurs with those of Oduol(2015) that provision of clear instructions, procedures and processes for employees made staff perform work efficiently in commercial banks in Kenya, thus improving banks performance. However, in realization that correlation is not causation, the present study goes on to isolate the magnitude of variation in bank performance that could be accounted for by variation in corporate culture. Moreover, the study revealed that leadership style influences bank performance. This supports findings that report individual management style as relating directly with corporate performance (Haakonsan et.al, 2008). Nevertheless, whereas previous studies have dwelt on existing relationships between leadership and performance, the present study highlights the predictive ability of leadership style on bank performance thereby exploiting causality between the two variables.

The finding showing that leadership positively and significantly influences bank performance contradicts findings by Nyamogo and Temesgen (2013), showing that corporate culture may not necessary impact firm performance positively but could also occasion negative impacts. Such contradiction is manifestation enough that the context of study is perhaps a variable of necessity in firm performance. The contention of the study is therefore that validity of findings relating corporate culture to bank performance can only be enhanced if the study context is controlled for in such studies. This may however not be easy to achieve considering different dynamics required for different businesses.

Commercial banks should however continue to cultivate strong cultures since results in the study reflect many others in extant literature and clearly identify dimensions such as core values, procedures and processes and employee involvement as corporate culture aspects of concern (Luqman, Khan \& Shabir, 2012; Oduol, 2015; Shalizad,; Stewart 2010). Indeed the finding that team work influences bank performance positively as found out in the present study augers quite well with the intention of commercial banks in Kenya to perform well.
An important point to note is that the study finds corporate culture as a major contributor to bank performance. This should perhaps have been expected since corporate culture which involves sharing of values, beliefs and organizational norms has been found to be the basis upon which strategy formulation revolves (Muthomi, 2012). Conformity to proper practices of corporate culture can therefore lead to strategy formulation and implementation that may facilitate towards gaining of competitive advantage on the market by oganizations. Therefore, practicing managers need to cultivate a strong corporate culture among themselves and their staff if they have to improve on their performance. This in essence explains the findings of the present study with regard to the contribution of corporate culture to bank performance.

The level of use of innovation as a dimension of corporate culture was relatively lower in comparison with the other dimensions. The finding reflects views by Marons (2015) that despite innovation being a proven requirement for differentiation and competitiveness, potential meaningful advancements of innovativeness in banks is curtailed by unfocused approach to operations, short term focus and risk averse culture. Marons argues that banks face the challenge of having surplus ideas that remain un-nurtured. It is the contention of the present study that although corporate culture significantly impacts on the performance of commercial banks in Kenya, individual banks have the onus to harness and nurture employee idea creation in order to promote innovation and creativity.

The results of the present study that corporate culture influences firm performance, contradicts those of Wilderom et.al (2000) that corporate culture can also be a silent killer if not aligned to firm's mission and vision. Corporate culture dimensions are numerous. Previous studies on how corporate culture influences firm performance was concluded on one or few elements of corporate culture. However, the present study adopted structure, teamwork, leadership and innovativeness as elements of corporate culture. Therefore, the contributions of this study are the findings on how corporate culture influences bank performance in Kenya.

\section{Conclusions}

A strong and positive corporate culture adoption by commercial banks potentially leads to improved performance. Commercial banks in Kenya have as a result put in place mechanisms to oversee high use of corporate culture dimensions such as structure, teamwork, leadership, and innovativeness. Use of the four culture dimensions was however, restrictive in terms of depth as well as diversity. This has facilitated to high rate of customer retention which is attributed to prompt response to customers' complaints, suggestions and compliments. In addition, customer loyalty among commercial banks in Kenya relatively high and this is 
associated to increase in the number of banking services or service portfolio and bonding of customers with nontraditional banking services such as overdraft and loans. Finally, commercial banks in Kenya have consistently maintained good reputation on the market through provision of high quality services, customer oriented staff and high level of involvement in corporate social responsibility activities.

\section{Recommendations}

The study reported that corporate culture dimensions of structure, teamwork, leadership and innovativeness adopted by commercial banks in Kenya, highly influenced banks' customer retention, loyalty as well as improving banks' image. It is therefore recommended that the management of commercial banks in Kenya should foster on nurturing and building strong corporate culture that would make both management team and employees have identity with the bank and work to achieve a common goal.

\section{References}

[1]. Aktas, E., Cicek, I., \& Kiya, M. (2011). The effect of organizational culture on organization efficiency: The moderating role of organizational environment and CEO values. International strategic management conference, Procedia Social Behavioural Sciences, 24(2011): 1560 1573) / doi: 10. 1016/j.sbspro.2011.09.092.

[2]. Berson, Y., Oreg, S., \& Dyir, T. (2005). Organizational culture as a mediator of CEO values and organizational performance. Academy of Management Best Conference paper, Israel.

[3]. Cameron, K. S., \& Quinn, R. E. (1999). Diagnosing and changing organizational culture: The competing values framework: Reading MA: Addison-Wesley.

[4]. Carreta, A., Farina, V., \& Schwizer, P. (2006). Corporate culture and shareholder value in banking industry. MPRA paper No. 8304.

[5]. Emercy ,R.C., College,E., Barker,,J., \& Katherine, F. S. ( 2007 ). The effect of transactional and transformational leadership styles on the organizational commitment and Job satisfaction of customer contact personnel. Journal of organizational culture, communication and conflict, 11 (1): $77-90$.

[6]. Alexandrov, A., Babakus, E., \& Yavas, U. (2007). The effects of perceived management concern for frontline employees and customers on turnover intentions: Moderating roles of employment status. Journal of Service Research, 9 (4):356 371.

[7]. Brooks, I.. (2006). Organizational Behaviour: Individuals, Groups and Organization. Essex: Pearson Education Limited.

[8]. Cameron, K. S., \& Quinn, R. E. (1999). Diagnosing and changing organizational culture: The competing values framework: Reading MA: Addison -Wesley.

[9]. Carreta, A., Farina, V., \& Schwizer, P. (2006). Corporate culture and shareholder value in banking industry. MPRA paper No. 8304.

[10].Emercy ,R.C., College,E., Barker,,J., \& Katherine, F. S. (2007). The effect of transactional and transformational leadership styles on the organizational commitment and Job satisfaction of customer contact personnel. Journal of organizational culture, communication and conflict, 11 (1): $77-90$.

[11]. Farashahi, M., Hafso, T., \& Molz, R. (2005). Institutionalised norms of conducting trsearch and social realities: A research synthesis of empirical works from 1983 to 2002. International journal of management review, 7(1): 1- 24.

[12]. Haakonsan, D. D.,Bueton, R.M., Obel, B.,\& Lauridhn, J. (2008). How failure to align organizational climate and leadership style affects performance. Management Decision, 46(3): $406-432$.

[13]. Hodgetts, L., \& Luthans, F. (2003). International management: Culture, Strategy, and Behaviour. $5^{\text {th }}$ edition , New York, McGraw - Hill / Irwin.

[14]. Janicijevic, N. (2012). Organizational culture and strategy, Scientific Paper, 127 - 140 / UDF: 005. 72: 005.21.

[15]. Kwantes, C. T., \& Boglarsky, C. A. (2007). Perceptions of organizational culture, leadership effectiveness and personal effectiveness across six countries. Journal of international management, 13(1): $204-213$.

[16]. Langan - Fox, J,\& Philomena, T. (1997). Images of a culture in transition, personal constructs of organizational stability and change. Journal of occupational and organizational psychology. 70(3): $273-329$.

[17]. Lee, T. Z., \& Tseng,Y. F. (2005). Astudy of the relationship between organizational culture and organizational effectiveness in Taiwan, Research Institute of mathematical sciences 14(91): 161- 178).

[18]. Nyamongo, E.M., \& Temesgen, K. (2013). The effect of governance on performance of commercial banks in Kenya: A panel study, corporate governance. The International Journal of Business in Society, 13 (3): 236-248.

[19]. Oduol, S. M. (2015). Effects of organizational culture on performance of subsidiaries of selected regional commercial banks H/QS in Kenya.MBA, research project, University of Nairobi.

[20]. Owino, J. O., Kibera, F., \& Musyoka, R. (2015). The influence of organizational culture and marketing capabilities on performance of microfinance institutions in Kenya, Journal of marketing management, 3(1): $91-99$.

[21]. Robbins,S.P., \& Sanghi, S. (2007). Organizational Behaviour, New Delhi, Pearson Education Limited.

[22]. Rogg,,L..K., Schmidt, B.D., Schmidt, N., \& Shull, C.(2001). Human resource practices, organizational climate and customer satisfaction. Journal of Management , 27 (4): $.431-449$.

[23].Steward, D. (2010). Growing the corporate culture,obtained from; https; // www.wachovia.com/ foundation/v/ index.jsp?vgnextoid=ab411fo776aa110vgn vcmi ooooo4b od1872.

[24].Shahzad, F., Luqman, R.A., Khan, A. R., Shabbir, L. (2012). Impact of organizational culture on organizational performance: An Overview, Interdisciplinary journal of contemporary research in business, 3(9): $975-985$.

[25]. Ugboro, O.I., \& Obeng, K. (2000). Top management leadership,employee empowerement, ,job satisfaction, and customer satisfaction in TQM organizations: An empirical study. Journal of Quality Management, 5(2): 247 - 272.

[26].Verhoef, C. P. ( 2003 ). Understanding the effect of customer relationship management on customer retention and customer share development, Journal of marketing, 6(4): $30-45$

[27]. Wallachi, J. E.(1983). Individuals and organizations: The cultural match, training \& development journal, 37(2): 29 36.

[28]. Wilderom, C. et.al. (2000). Organizational culture as a predictor of organizational performance, in Ashkaasy . N. et.al (eds) Handbook of organizational culture and climate, page, 193 - 209,Thousand Oakis: Sage. 